\title{
Electrospray Ionization Mass Spectrometry and Ion Mobility Analysis of the 20S Proteasome Complex
}

\author{
Joseph A. Loo, Beniam Berhane, Catherine S. Kaddis, \\ Kerry M. Wooding, and Yongming Xie \\ Department of Chemistry and Biochemistry, University of California-Los Angeles, Los Angeles, California, \\ USA
}

Stanley L. Kaufman

TSI, Inc., St. Paul, Minnesota, USA

Igor V. Chernushevich

MDS Sciex, Concord, Ontario, Canada

Mass spectrometry and gas phase ion mobility [gas phase electrophoretic macromolecule analyzer (GEMMA)] with electrospray ionization were used to characterize the structure of the noncovalent 28-subunit 20S proteasome from Methanosarcina thermophila and rabbit. ESI-MS measurements with a quadrupole time-of-flight analyzer of the $192 \mathrm{kDa} \alpha_{7}$-ring and the intact $690 \mathrm{kDa} \alpha_{7} \beta_{7} \beta_{7} \alpha_{7}$ are consistent with their expected stoichiometries. Collisionally activated dissociation of the 20S gas phase complex yields loss of individual $\alpha$-subunits only, and it is generally consistent with the known $\alpha_{7} \beta_{7} \beta_{7} \alpha_{7}$ architecture. The analysis of the binding of a reversible inhibitor to the $20 \mathrm{~S}$ proteasome shows the expected stoichiometry of one inhibitor for each $\beta$-subunit. Ion mobility measurements of the $\alpha_{7}$-ring and the $\alpha_{7} \beta_{7} \beta_{7} \alpha_{7}$ complex yield electrophoretic diameters of 10.9 and $15.1 \mathrm{~nm}$, respectively; these dimensions are similar to those measured by crystallographic methods. Sequestration of multiple apo-myoglobin substrates by a lactacystin-inhibited 20S proteasome is demonstrated by GEMMA experiments. This study suggests that many elements of the gas phase structure of large protein complexes are preserved upon desolvation, and that methods such as mass spectrometry and ion mobility analysis can reveal structural details of the solution protein complex. (J Am Soc Mass Spectrom 2005, 16, 998-1008) @ 2005 American Society for Mass Spectrometry

$\mathrm{T}$ The structural determination of protein complexes can play an important role in the fundamental understanding of biochemical pathways. "Every major process in a cell is carried out by assemblies of 10 or more protein molecules ... . The entire cell can be viewed as a factory that contains an elaborate network of interlocking assembly lines, each of which is composed of a set of large protein machines [1]." Francis Collins of the National Human Genome Research Institute states that "genes and gene products do not function independently, but participate in complex, interconnected pathways, networks, and molecular systems that, taken together, give rise to the workings of cells, tissues, organs, and organisms. Defining these systems and determining their properties and interactions is

Published online May 23, 2005

Address reprint requests to Dr. J. A. Loo, Department of Chemistry and Biochemistry, University of California-Los Angeles, 402 Paul D. Boyer Hall/MBI, Los Angeles, CA 90095-1570, USA. E-mail: JLoo@chem.ucla.edu crucial to understanding how biological systems function [2]." Proteins interact both nonspecifically and specifically; however, the specific interactions are important because of the downstream consequences they can presage. These consequences include inducing a change in the structure of an interaction partner, stabilizing or destabilizing an interaction partner, modifying the activity of a protein (activate, inhibit, or otherwise regulate), causing an interaction partner to move to another location, cutting an interaction partner, and chemically modifying an interaction partner (i.e., posttranslational modification).

With information from the Human Genome Project comes a new revolution in proteomics [3], in which researchers are trying to determine how genes function within the genome and how they communicate with each other. These efforts may lead to important new insights into disease mechanisms and improved drug discovery strategies. The proteome is the protein complement to the genome. To study protein function on a 
wide scale, methods are being developed to identify the locations of proteins, their cellular levels, their structures, how they are modified, and their interactions with other proteins [4]. The development of new bioanalytical tools, such as mass spectrometry (MS), to view large assemblies can have a profound role in the functional understanding of a protein.

Techniques based on mass spectrometry and gas phase methods have been developed to facilitate the characterization of the proteome and its protein assemblies. Specifically, from the initial pioneering development of electrospray ionization (ESI) by 2002 Nobelist John Fenn [5], the application of ESI-MS for studying noncovalent complexes has utility in biology, biochemistry, and biomedical research [6-8]. The ability of electrospray to preserve elements of the native structure directly results from the gentleness of the overall method, i.e., dissociation of the ESI-generated gas phase complex is minimal. The determination of molecular mass can be used to augment the study of macromolecular assemblies and their individual components. The molecular mass measurement provides a direct readout of the stoichiometry of the binding partners in the complex, even for multi-ligand hetero-complexes. For many cases investigated by ESI-MS, the complex stoichiometry for the gas phase complex is consistent with that expected for the solution phase complex $[9,10]$.

The mass spectrometry method requires the promotion of the solution phase protein complex to the gaseous state. Several studies have suggested that some higher order elements of the solution phase structure are preserved in the dehydrated complex [11]. In general, a high correlation has been found between ESI-MS data and expectations based on solution phase results [6]. MS has not progressed to the stage to address whether the precise three-dimensional structure of the gas phase molecule or complex is the same as the solvated species. However, some structural elements may be preserved upon transition to the gaseous state. The physical characteristics of the gas phase complex, such as their dissociation behavior and their topographical features, are consistent with information gathered from other biophysical experiments designed to probe the solution complex. Collision cross-section measurements by ESI-ion mobility and ion scattering measurements [12-14], hydrogen-deuterium exchange studies, and blackbody infrared dissociation (BIRD) experiments [15] have suggested that different gas phase protein conformers can be measured. Studies of a virus or an enzyme collected post-ESI mass spectrometry demonstrated that the ESI and desolvation processes are not destructive, as the biological molecules remained bioactive after exposure to vacuum. However, they do not indicate directly the structure of the gas phase (or solution phase) complex [16, 17]. Robinson and coworkers have provided numerous examples of collisionally activated dissociation (CAD) of large protein complexes; many of the examples, including the ribosome, found consistency between the known stabil- ities of the solution complex and the dissociative behavior of gas phase noncovalent complexes. They have been able to differentiate electrostatic and hydrophobic contributions to the structural stability of protein complexes $[7,18,19]$. In one case from our laboratory, the tertiary geometry of a cyclic polypeptide was probed by CAD; its CAD behavior suggested that noncovalent interactions necessary to maintain its three dimensional structure is preserved in its gas phase molecule [20].

A primary advantage of MS-based methods is the ability to study the intrinsic factors related to protein stability not related to solvation and hydration. The forces involved with protein hydration that enhance protein complex stability may not be necessary for its stability in the gas phase. How the solventless environment affects the ability of mass spectrometry to probe the solution characteristics of large biomolecules is a central question. Can the measurement of gas phase molecules be related to the original solution phase? What is the fidelity between the gas phase and solution structure? In general, the strongest correlations for the ESI-MS experiments to the solution phase are found in the stoichiometry measurements and the observed relative abundances. But a close correspondence between the expected mass and the measured mass of the complex does not ensure fidelity of the structure of the complex.

There have been relatively few studies that have compared directly the physical geometric size of electrospray-generated gas phase protein complexes with the data obtained by other structural tools, such as X-ray crystallography and NMR [21]. A number of very large protein complexes have been measured by ESI-MS $[6,8,9]$. Because of its high sensitivity and moderate resolution at very high $m / z$ (e.g., above $m / z$ 6000), the time-of-flight (TOF) analyzer provides an ideal system for large noncovalent complexes, and it is considered the standard system today for such analyses. Standing and coworkers first demonstrated its potential for large protein complexes by measuring ESI mass spectra of soybean agglutinin and a variety of other protein systems [22]. Among the largest complex measured by ESI-MS is the 2.5 MDa bacteriophage MS2 virus capsid composed of 180 copies of the viral coat protein [23]. Several other reports of complexes in excess of $500 \mathrm{kDa}$ have been described [24], including the $800 \mathrm{kDa}$ chaperonin GroEL 14-mer assembly [25] and the intact 850 $\mathrm{kDa} 30 \mathrm{~S}$ subunit of the E. coli ribosome, composed of 21 protein components and the 16S RNA molecule [18]. Heck and coworkers have measured mass spectra for the 0.5 MDa octamer, 1.0 MDa octamer-dimer, and 1.5 MDa octamer-trimer complexes of the vanillyl-alcohol oxidase enzyme [26] and the H. pylori urease complex of $1.06 \mathrm{MDa}$ [27].

We have analyzed the $690 \mathrm{kDa} 20 \mathrm{~S}$ proteasome complex by ESI-MS and by gas phase ion mobility analysis coupled with charge-neutralized electrospray and compared the results to their crystallographicallyderived dimensions [28]. The proteasome is a multicata- 
lytic enzyme complex expressed in the nucleus and cytoplasm of all eukaryotic cells [29, 30]. The proteasome is a recycler of damaged, misfolded, and shortlived regulatory proteins, and it is of critical importance to cell cycle and cell survival. It is the central enzyme of nonlysosomal protein degradation (i.e., the ubiquitinproteasome pathway). Because the proteasome cleaves numerous cell cycle regulators, antigenic proteins, and transcription factors, it is an attractive target for the development of drugs for the treatment of cancer, autoimmune diseases, inflammation, and other pathological states [31]. Currently, competitive inhibitors of proteasome activity are in clinical trials involving multiple cancers and stroke. The 2004 Nobel Prize in Chemistry was awarded to Aaron Ciechanover, Avram Hershko, and Irwin Rose for their elucidation of regulated protein degradation by the proteasome. The unique structure of the $20 \mathrm{~S}$ proteasome allowed for comparison of its gas phase properties, including reactivity with small molecule inhibitors, with its known solution features.

\section{Experimental}

A nanoESI-QqTOF analyzer (QSTAR Pulsar XL, $\mathrm{m} / \mathrm{z}$ range 40,000; Applied Biosystems/MDS Sciex, Concord, ON, Canada) was used for the ESI-MS experiments with the $\alpha$-subunit proteasome [32]. A prototype QqTOF analyzer optimized for MS and MS/MS of large molecular weight protein complexes previously described was used for the analysis of the intact 205 proteasome [33]. Borosilicate glass nanospray emitters that are coated with $\mathrm{Au} / \mathrm{Pd}$ to allow for $10-50 \mathrm{~nL} / \mathrm{min}$ spray operation were obtained from Proxeon (Odense, Denmark).

For the ion mobility experiments, a gas phase electrophoretic mobility macromolecule analyzer (GEMMA, Model 3890, TSI Inc., Shoreview, MN) was used. The details of the GEMMA instrumentation and method for measuring protein size have been described elsewhere [34-36]. Briefly, the GEMMA instrument consists of an electrospray ionization unit with a neutralizing chamber, a differential mobility analyzer (DMA) and a condensation particle counter (CPC). Multiply charged droplets generated by electrospray are charge reduced by interaction with ions formed by $\alpha$-radiation $\left({ }^{210} \mathrm{Po}\right)$. The droplets ultimately evaporate, leaving macromolecular ions of low charge as residues [37]. ${ }^{\circ}$ The $^{\circ}$ singly $^{\circ}$ charged $^{\circ}$ ions $^{\circ}$ pass through a scanning differential mobility analyzer and are counted by a condensation particle counter. An electrical mobility diameter is measured as a result of the ion mobility analysis. Protein solutions are introduced via the ESI source at a flow rate of approximately $70 \mathrm{nl} / \mathrm{min}$. Each sample concentration was run at least three times. Protein solutions for the ESI-MS experiments were 1-10 $\mu \mathrm{M}$, and $1 \mathrm{nM}$ (in $10 \mathrm{mM}$ ammonium acetate, $\mathrm{pH}$ 7.5) for the GEMMA experiments. Solutions were desalted and concentrated by centrifugal filtration using Microcon or Ami- con Ultra-4 filters (Millipore, Bedford, MA) for both the ESI-MS and GEMMA experiments.

For the binding reaction of lactacystin to the $20 \mathrm{~S}$ proteasome, $2 \mu \mathrm{L}$ of $1.55 \mu \mathrm{M} 20 \mathrm{~S}$ proteasome was added to $2 \mu \mathrm{L}$ of $0.5 \mathrm{nmol} / \mu \mathrm{L}$ lactacystin. A solution of $20 \mathrm{mM}$ ammonium acetate, $\mathrm{pH} 7.5$ was added to the sample to bring the total volume to $30 \mu \mathrm{L}$. The solution was incubated at $37^{\circ} \mathrm{C}$. Matrix-assisted laser desorption/ionization (MALDI)-MS experiments were performed with a Voyager DE-STR TOF analyzer (Applied Biosystems, Foster City, CA). For the protein MALDI-MS measurements, sinapinic acid was used as the matrix.

The Methanosarcina thermophila 20S proteasome, $\alpha$-subunit, lactacystin, and ALLN were obtained from Calbiochem (San Diego, CA). The 20S proteasome from rabbit and equine apo-myoglobin was obtained from Sigma Chemicals (St. Louis, MO).

\section{Results and Discussion}

\section{ESI-MS and Collisionally Activated Dissociation of the $20 S$ Proteasome}

The $20 \mathrm{~S}$ proteasome enzyme is a giant assembly of multiple ${ }^{\circ}$ subunits ${ }^{\circ}[38]^{\circ} .^{\circ}$ Its $^{\circ} 28^{\circ}$ subunits $^{\circ}$ of $^{\circ}$ the ${ }^{\circ} 20 \mathrm{~S}^{\circ}$ catalytic core are arranged into four stacked rings, each containing seven subunits. The outer $\alpha$-rings contain only noncatalytic $\alpha$-subunits, whereas each of the two inner $\beta$-rings harbor three active centers concealed inside the barrel-like structure with the N-terminal Thr residues as the catalytic centers. The $20 \mathrm{~S}$ particle with attached two 19S complexes forms the complete $26 \mathrm{~S}$ proteasome responsible for recognition and degrada-

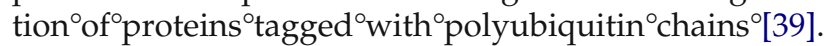
The first crystal structures of the 20S proteasome were from archeae systems, showing the $\alpha_{7} \beta_{7} \beta_{7} \alpha_{7}$ stoichiometry in which each of the $\alpha$-subunits and each of the $\beta$-subunit ${ }^{\circ}$ are $^{\circ}$ identical $^{\circ}[40]^{\circ}$ Initial $^{\circ}$ studies $^{\circ}$ of $^{\circ}$ mamma- $^{\circ}$ lian proteasomes show similar architecture, with differences in the size of the internal cavity; mammalian proteasomes show a more closed cavity, with its opening regulated by substrate introduction and the activity of the ${ }^{\circ} 19 S^{\circ}$ assembly $[41]$.

ESI-MS of the $\alpha$-subunit from archaeon Methanosarcina thermophila under $\mathrm{pH} 7.5$ native solution conditions shows $^{\circ} \mathrm{a}^{\circ}$ molecular $^{\circ}$ mass $^{\circ}$ of $^{\circ} 191.9^{\circ} \mathrm{kDa}^{\circ}$ (Figure $^{\circ} 1 \mathrm{a}$ ), consistent with the expected value $(191.9 \mathrm{kDa})$ for a heptameric $\alpha_{7}$ ocomplex [42]. ${ }^{\circ}$ ESI-MS ${ }^{\circ}$ f ${ }^{\circ}$ the ${ }^{\circ}$ full ${ }^{\circ} \alpha_{7} \beta_{7} \beta_{7} \alpha_{7}$ $20 S$ proteasome from $M$. thermophila yields a molecular mass of approximately $690.5 \mathrm{kDa}$ (theory $689.3 \mathrm{kDa}$ ) with ${ }^{\circ}$ multiply ${ }^{\circ}$ charged $^{\circ}$ ions $^{\circ}$ found ${ }^{\circ} t^{\circ} \mathrm{m} / z$ 11, $000^{\circ}$ (Figure 2a). ${ }^{\circ}$ Other $^{\circ}$ lower $^{\circ}$ abundance ${ }^{\circ}$ protein $^{\circ}$ clusters $^{\circ}$ are $^{\circ}$ observed at higher $\mathrm{m} / \mathrm{z}$. Ions representing a $20 \mathrm{~S}$ dimer (or 2 times $\alpha_{7} \beta_{7} \beta_{7} \alpha_{7}$ ) molecule of $1.39 \mathrm{MDa}$ are found at $\mathrm{m} / \mathrm{z}$ $14,000-16,000$. These are likely to be formed from nonspecific aggregation of the $20 \mathrm{~S}$ species in solution and/or in the gas phase, as previous structural studies have not identified an active, native $20 \mathrm{~S}$ dimer. Another 


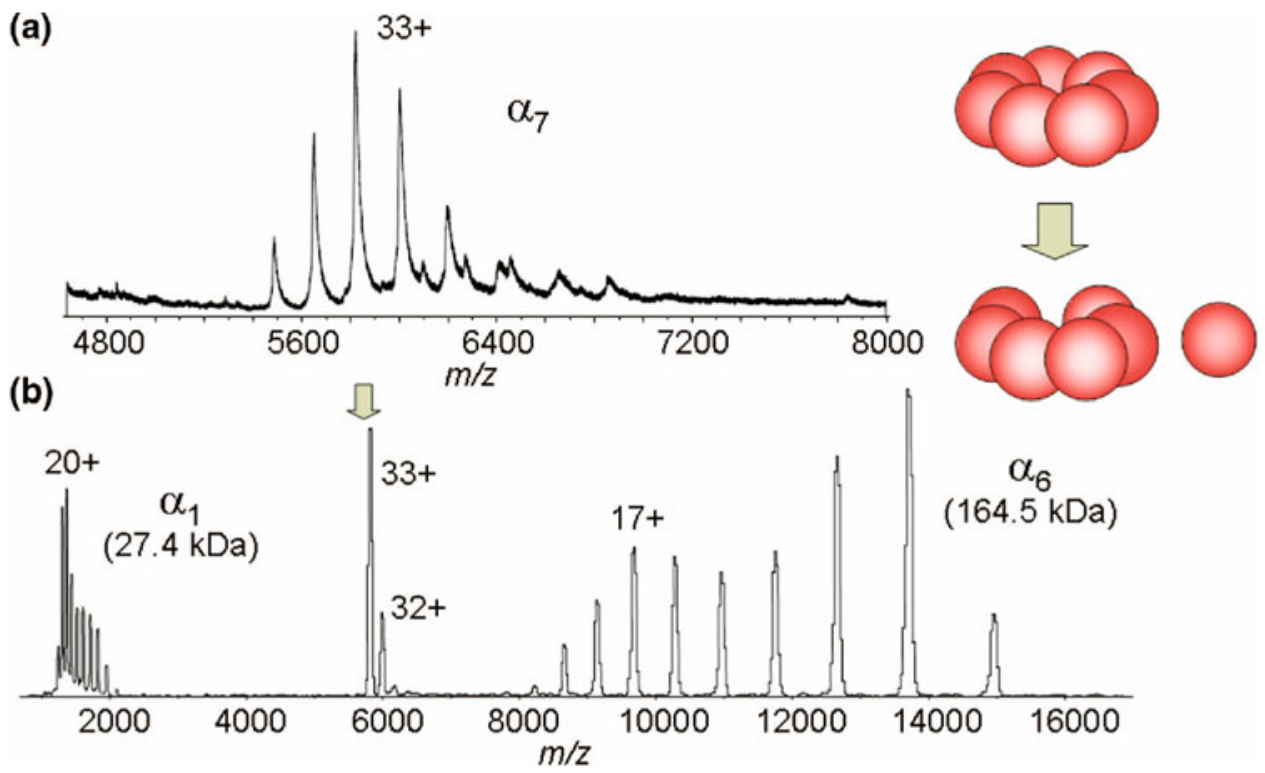

Figure 1. (a) ESI-MS of the $\alpha$-subunit from archaeon $M$. thermophila, showing multiply charged molecules for the $192 \mathrm{kDa} \alpha_{7}$ noncovalent complex. (b) ESI-MS/MS of the $33+$-charged $\alpha_{7}$ precursor yields the $\alpha_{1}$ and $\alpha_{6}$ products.

cluster of multiply charged molecules is found at $\mathrm{m} / \mathrm{z}$ $12,000-13,500$ and centered at $80+$ charges; molecular mass measurements indicate a size of approximately 1.02 MDa. The closest theoretical composition to match the experimentally measured value is a complex with a stoichiometry of $\alpha_{7}\left(\beta_{7} \beta_{7}\right)_{2} \alpha_{7}$, or $\alpha_{14} \beta_{28}$. Similar to the observed $20 \mathrm{~S}$ dimer, a $\alpha_{14} \beta_{28}$ species is not consistent with any known proteasome architecture. However, it is difficult to rationalize the formation of the $\alpha_{14} \beta_{28}$ complex as nonspecific gas phase aggregation. The $\beta$-subunit nor the $\beta_{7}$-ring are not observed to dissociate from the 20S proteasome in solution nor in the gas phase (vide infra). It is believed that association of the $\beta$-subunit to form the $20 \mathrm{~S}$ complex requires its direct association with the $\alpha$-subunit, or perhaps with the $\alpha_{7}$-ring ${ }^{\circ}$ complex $^{\circ}[43] .{ }^{\circ}$ By $^{\circ}$ itself, ${ }^{\circ}$ the ${ }^{\circ} \beta$-subunit ${ }^{\circ}$ will ${ }^{\circ}$ not assemble into an aggregate $\left(\beta_{7}\right)$ in solution.

The dissociation of the gas phase proteasome complexes yields data that is similar to studies for other protein complexes. In general, collisionally activated dissociation of a large multiply charged complex held together through noncovalent bonding yields a liberated monomer (or a few subunits) and the remaining, much larger complex (minus the liberated molecule). Furthermore, the distribution of charge in the products is not evenly distributed. Jurchen and Williams have reported that the asymmetric charge distribution results from unfolding of the monomer product, thus exhibiting $^{\circ} \mathrm{a}^{\circ}$ more $^{\circ}$ flexible ${ }^{\circ}$ conformation ${ }^{\circ}[44]^{\circ}{ }^{\circ} \mathrm{CAD}^{\circ}$ of ${ }^{\circ}$ the $33+$-charged precursor ion for the $\alpha_{7}$ complex shows loss of $\alpha_{1}$ to ${ }^{\circ}$ form ${ }^{\circ}{ }^{\circ} \alpha_{6}{ }^{\circ}$ complex $^{\circ}$ (Figure $1 \mathrm{~b}$ ). ${ }^{\circ}$ However, the free $\alpha_{1}$ retains up to $22+$ charges, or approximately $67 \%$ of the total charge, although it accounts for only $14 \%$ of the mass of the original $\alpha_{7}$ complex. Likewise, the CAD-spectrum of the $63+$-charged $20 \mathrm{~S}$ proteasome generates the free $\alpha_{1}$ subunit with 15-28+ charges and the remaining $\alpha_{7} \beta_{7} \beta_{7} \alpha_{6}$ molecule with 35-44+ charges (Figure 3 ). ${ }^{\circ}$ The ${ }^{\circ} \alpha_{1}$ molecule retains approximately onethird of the total charge available onto a molecule that accounts for only $4 \%$ of the mass, presumably because it is liberated in more of an unfolded state than the remaining $\alpha_{7} \beta_{7} \beta_{7} \alpha_{6}$ complex.

Moreover, dissociation of the gas phase 20S complex generates product ions up to $\mathrm{m} / \mathrm{z} 35,000$ from the loss of only the $\alpha$-subunits, consistent with the known structure of the $\alpha_{7} \beta_{7} \beta_{7} \alpha_{7}$. complex. $^{\circ}{ }^{\circ}$ This ${ }^{\circ}$ is ${ }^{\circ}$ depicted $^{\circ}$ in ${ }^{\circ}$ Figure $^{\circ} 2 \mathrm{~b}$, showing the CAD-spectrum generated by increasing the orifice potential from $100 \mathrm{~V}$ to $300 \mathrm{~V}$ and inducing protein fragmentation in the atmosphere-vacuum interface. The loss of one and two $27.4 \mathrm{kDa} \alpha$-subunits is observed; the loss of $21.8 \mathrm{kDa} \beta$-subunits was not observed under these experimental conditions. The isoelectric points of the subunits are not sufficiently different (i.e., $\mathrm{pI}$ of the $\alpha$-subunit is 5.2 and the $\beta$-subunit $\mathrm{pI}$ is 6.6) to suggest their different gas phase behavior. Based on a $\alpha_{7} \beta_{7} \beta_{7} \alpha_{7}$ geometry, the loss of the outer $\alpha$-subunits would be favored more compared to loss of the internal $\beta$-subunits because of the reduced number of potential intermolecular proteinprotein contacts.

The ESI-MS/MS studies of the 20S proteasome from $M$. thermophila represent a near ideal situation because each of the seven $\alpha$-subunits of the $\alpha_{7}$-ring and the seven $\beta$-subunits $\beta_{7}$-ring are identical. The situation for $20 \mathrm{~S}$ proteasomes from higher order species is not as simple, as each of the $7 \alpha$-subunits and seven $\beta$-subunits are different, and additional heterogeneity may occur from potential post-translational modifications, such as phosphorylation. This is reflected in the ESI mass spectrum acquired under denaturing solution conditions of the $20 \mathrm{~S}$ proteasome 


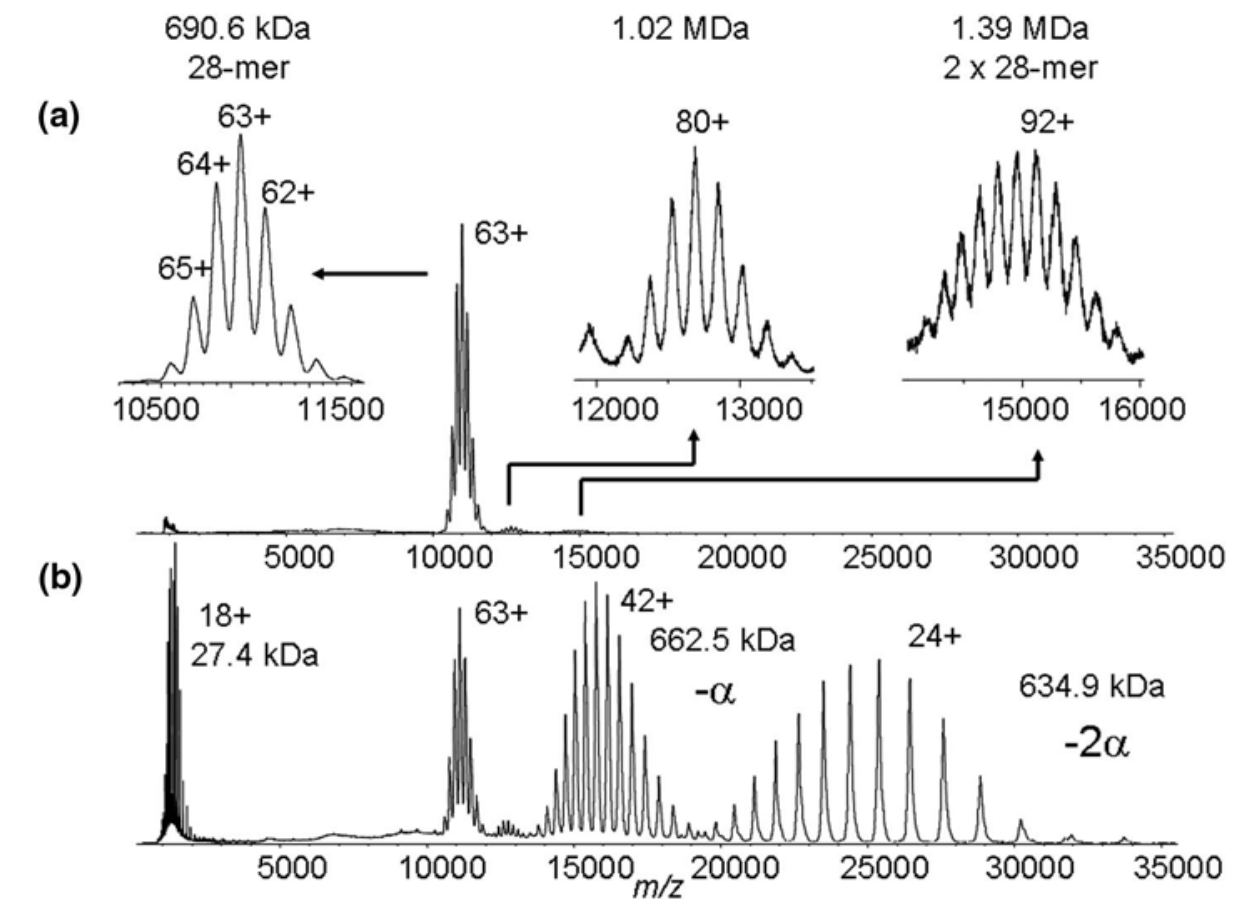

Figure 2. (a) ESI-MS of the M. thermophila $\alpha_{7} \beta_{7} \beta_{7} \alpha_{7} 28$-mer $20 \mathrm{~S}$ proteasome with an orifice potential of $+100 \mathrm{~V}$. Expansions are shown for the intact 20S complex (690 kDa), the 20S "dimer" (1.39 MDa), and a $20 \mathrm{~S}$ hybrid complex (1.02 MDa). (b) ESI-MS of the $20 \mathrm{~S}$ proteasome with the orifice potential of $+300 \mathrm{~V}$. Dissociation in the atmosphere/vacuum interface of the $\alpha_{7} \beta_{7} \beta_{7} \alpha_{7}$ complex yields the liberated $27.4 \mathrm{kDa} \alpha$-subunit and the remaining $\alpha_{7} \beta_{7} \beta_{7} \alpha_{6}$ (or $\alpha_{13} \beta_{14}$ ) and $\alpha_{12} \beta_{14}$ complexes.

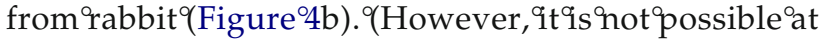
present to assign each subunit to a molecular mass because the amino acid sequences for the rabbit proteasome subunits are not available.) The ESI mass spectrum acquired under native solution conditions of the rabbit $20 \mathrm{~S}$ complex shows a relatively heterogeneous distribution of peaks in the $\mathrm{m} / \mathrm{z} 10,000-$ 12,000 range that reflects a molecular mass of approximately ${ }^{\circ} 698^{\circ} \mathrm{kDa}^{\circ}$ (Figure $\left.{ }^{\circ} 5 \mathrm{a}\right) .^{\circ} \mathrm{A}^{\circ}$ more $^{\circ}$ accurate measurement is difficult because of peak broadness. CAD of the rabbit $20 \mathrm{~S}$ complex shows peak distributions similar to the M. thermophila 20 S proteasome, suggesting that the loss of one and two $\alpha$-subunits are the $^{\circ}$ preferred $^{\circ}$ dissociation $^{\circ}$ pathways $^{\circ}$ (Figure $^{\circ} 5 b$ ). However, the low sensitivity and the broad peaks preclude any judgement on the identity of the dissociated $\alpha$-subunits at present.

The ESI mass spectra of the $20 \mathrm{~S}$ proteasome were

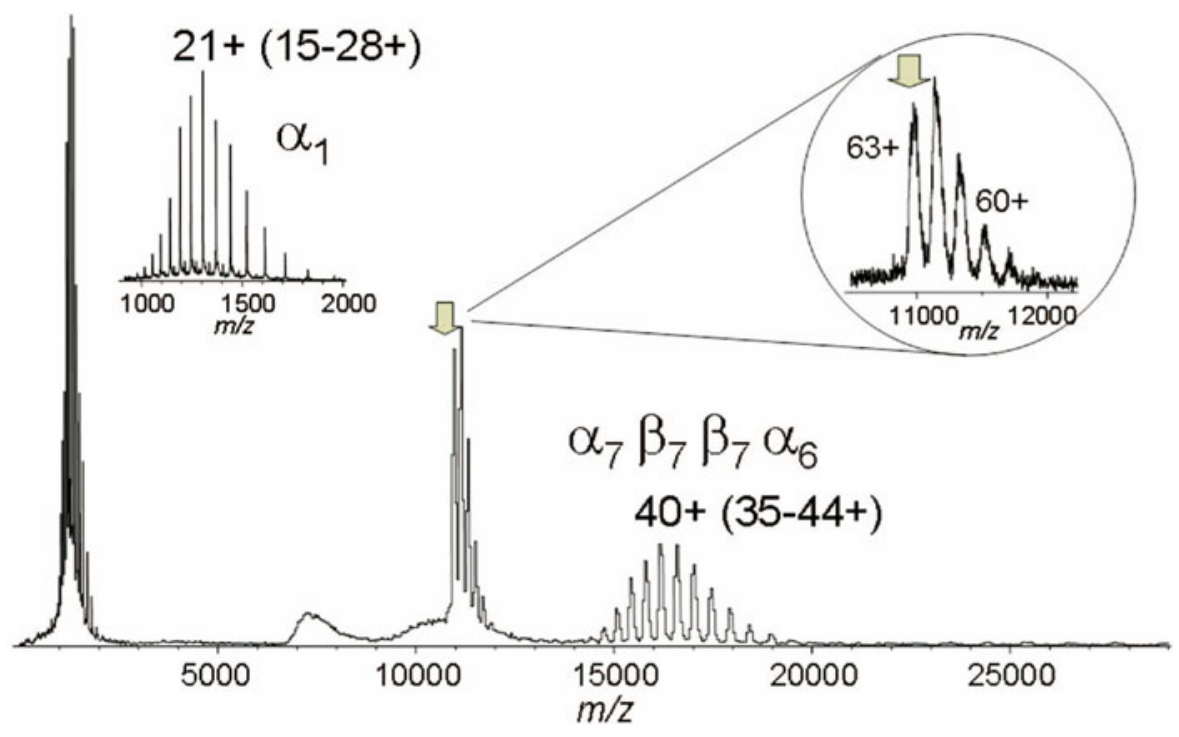

Figure 3. ESI-MS/MS of the 63+-charged $\alpha_{7} \beta_{7} \beta_{7} \alpha_{7} 28$-mer $20 \mathrm{~S}$ proteasome from $M$. thermophila. 


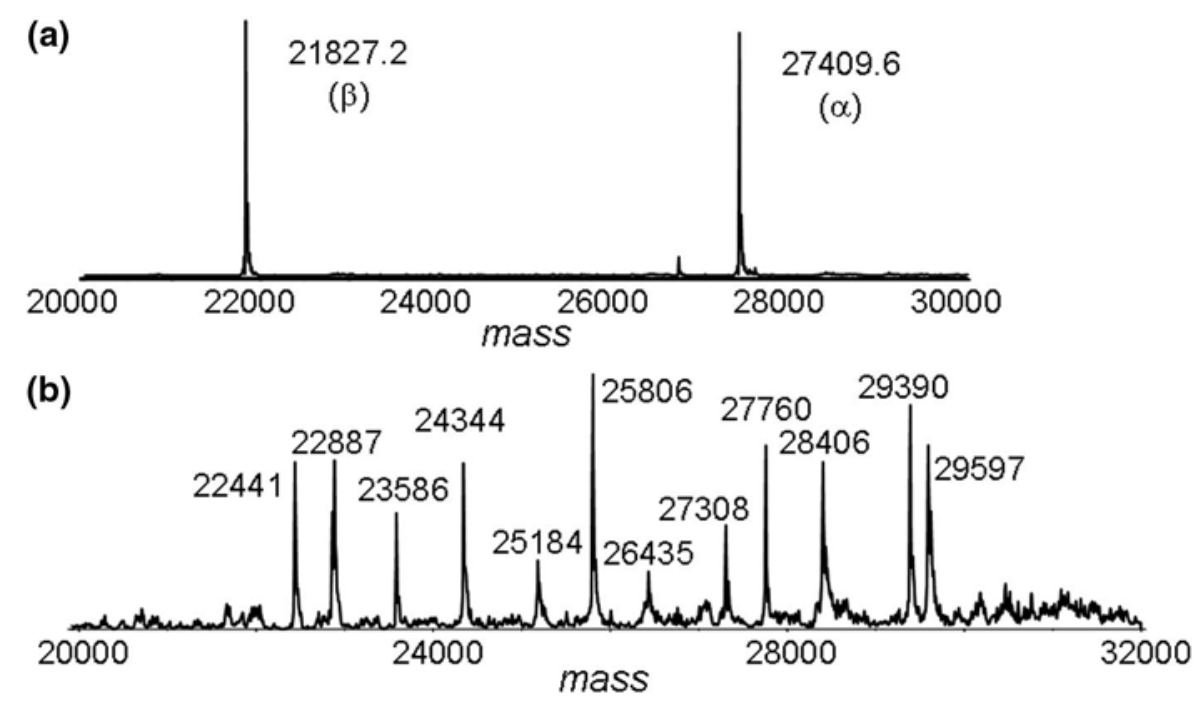

Figure 4. Deconvoluted ESI mass spectra of denatured 20 S proteasomes (50\% acetonitrile with $1 \%$ acetic acid) from (a) $M$. thermophila and (b) rabbit.

acquired with a prototype QqTOF system. Several recent reports have shown that transmission of high mass ions requires pressures in the first vacuum stages of the mass $^{\circ}$ spectrometer $^{\circ}$ to $^{\circ}$ be $^{\circ}$ increased $\left[19,{ }^{\circ} 24,{ }^{\circ} 45,{ }^{\circ} 46\right]$. Krutchinsky et al. have suggested that larger ions may acquire substantial kinetic energies (of more than 1000

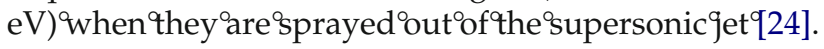
It is now widely accepted that a combination of collisional cooling and focusing of the ions and more efficient desolvation is effective for enhanced detection of ions with high $\mathrm{m} / \mathrm{z}$ values. Recently, a prototype ESI-QqTOF system has been built with improved sensitivity ${ }^{\circ}$ for ${ }^{\circ}{ }^{\circ}$ ery ${ }^{\circ}$ large ${ }^{\circ}$ protein ${ }^{\circ}$ complexes $^{\circ}[33]$. Improvements in sensitivity for large protein complexes appear to derive from improved cooling and focusing in Q0 produced by raising the pressure in this region. No benefits from increasing the pressure in the nozzleskimmer region, as observed for orthogonal "Z-spray" interfaces ${ }^{\circ}[46]^{\circ}$, were $^{\circ}$ observed..$^{\circ}$ Compared $^{\circ}$ with $^{\circ}$ the commercially-available QqTOF mass spectrometer, the prototype QqTOF has a sensitivity gain range from tens to thousands for very large complexes (greater than 0.5 $\mathrm{MDa})$.

\section{ESI-MS of Inhibitor Binding} to the 20S Proteasome

ESI mass spectrometry has been applied to the binding of small molecular weight inhibitors to their macromolecular ${ }^{\circ}$ targets, ${ }^{\circ}$ including ${ }^{\circ}$ protein $s^{\circ}\left[47,{ }^{\circ} 48\right]^{\circ}$ and $^{\circ}$ nucleic acids $^{\circ}[49]^{\circ}{ }^{\circ}$ The ${ }^{\circ}$ noncovalent ${ }^{\circ}$ binding $^{\circ}$ of $^{\circ}$ small ${ }^{\circ}$ molecule

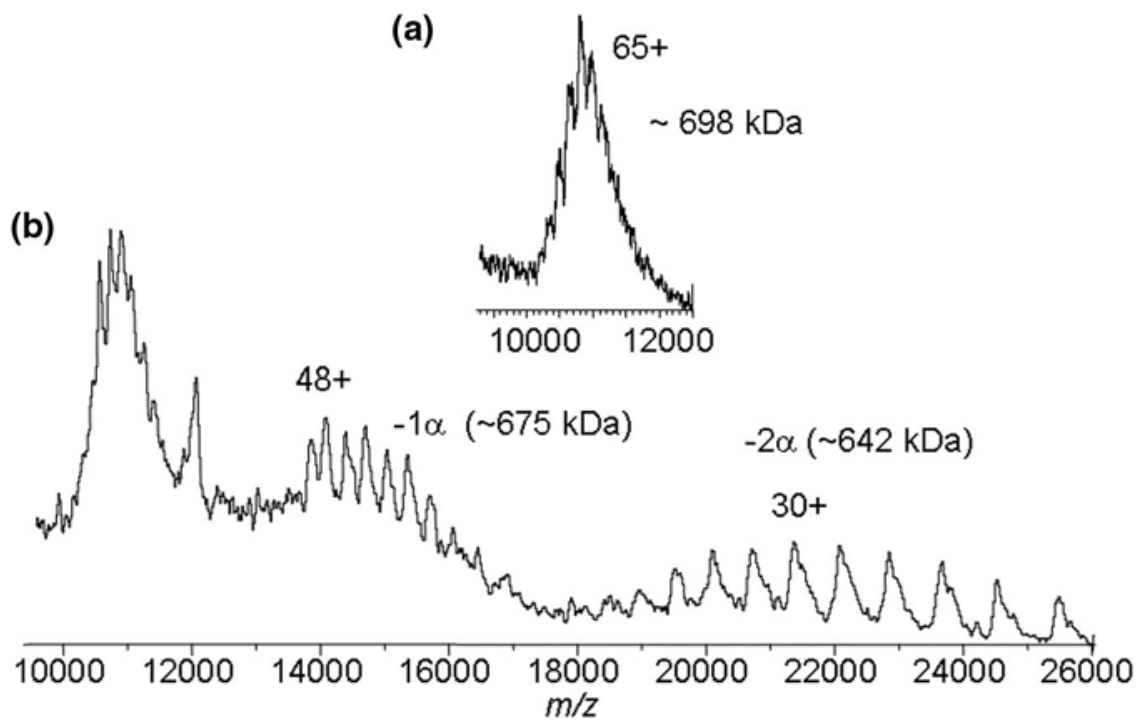

Figure 5. ESI-MS mass spectra of rabbit $20 \mathrm{~S}$ proteasome $(10 \mathrm{mM}$ ammonium acetate) with an orifice potential of $(\mathbf{a})+100 \mathrm{~V}$ and $(\mathbf{b})+350 \mathrm{~V}$. 
inhibitors can be readily measured by ESI-MS, and this strategy can be applied to screen libraries of potential drugs for the pharmaceutical industry. We attempted to measure the binding stoichiometry of the reversible aldehyde inhibitor ALLN (Ac-Leu-Leu-Nle-CHO, $\mathrm{M}_{\mathrm{r}}$ $383.5)$ to the M. thermophila 20 S proteasome by ESI-MS. Protease activity of the proteasome is inhibited by molecules that bind to the interior surface formed by the two $\beta_{7}$-rings of the complex. The $\mathrm{x}$-ray crystal structure of the $20 \mathrm{~S}$ proteasome in complex with ALLN shows $^{\circ}$ binding $^{\circ}$ to $^{\circ}$ each $^{\circ} \beta$-subunit ${ }^{\circ}[40]^{\circ}{ }^{\circ}$ The $^{\circ}$ ESI $^{\circ}$ mass spectra of the 20S-ALLN complex shows a molecular mass increase of $5410 \mathrm{Da}$ (5369 Da expected) that is consistent for the binding of 14 ALLN molecules (or 1 molecule per $\beta$-subunit) to form a noncovalent complex composed of 42 entities $\left(\alpha_{7} \beta_{7} \beta_{7} \alpha_{7}-\mathrm{ALLN}_{14}\right)^{\circ}$ (Figure $\left.{ }^{\circ} 6\right)$.

The dissociation of the gas phase protein-inhibitor complex shows a stepwise release of bound inhibitor molecules. Increasing the orifice potential from 150 to $350 \mathrm{~V}$ induces the loss of one and two $\alpha$-subunits, similar ${ }^{\circ}$ to ${ }^{\circ}$ that ${ }^{\circ}$ shown $^{\circ}$ in ${ }^{\circ}$ Figure $^{\circ} 2 b^{\circ} .^{\circ}$ Starting ${ }^{\circ}$ from $^{\circ}$ the $\alpha_{7} \beta_{7} \beta_{7} \alpha_{7}-$ ALLN $_{14}$ complex, the $\alpha_{13} \beta_{14}$ complex from the loss of one $\alpha$-subunit shows a molecular mass of approximately $665.5 \mathrm{kDa}$ compared to $662.5 \mathrm{kDa}$ for the $\alpha_{7} \beta_{7} \beta_{7} \alpha_{7}$ as ${ }^{\text {othe }}{ }^{\circ}$ starting ${ }^{\text {material }}$ (Figure $2 \mathrm{~b}$ ); ; this $^{\circ}$ would be consistent for 10 ALLN molecules bound to $\alpha_{13} \beta_{14}$, or the loss of 4 out of 14 bound ALLN. Generation of the $\alpha_{12} \beta_{14}$ complex from the loss of two $\alpha$-subunits is accompanied by the release of all 14 ALLN molecules $\left(\mathrm{M}_{\mathrm{r}}{ }^{\circ} 635.0^{\circ} \mathrm{kDa}\right.$; ${ }^{\circ}$ see $^{\circ}$ Figure $^{\circ} 2 \mathrm{~b}^{\circ}$ for $^{\circ}{ }^{\circ}$ comparison).

The CAD behavior of the 20S proteasome is consistent for the architecture of the $\alpha_{7} \beta_{7} \beta_{7} \alpha_{7}$ solution complex, as the loss of the $\alpha$-subunit is preferred. Moreover, the binding stoichiometry of up to 14 molecules of ALLN is consistent for the known specificity of the inhibitor to the $\beta$-subunits. However, it is not clear whether the loss of two $\alpha$-subunits originates from the same $\alpha_{7}$-ring, i.e., $\alpha_{7} \beta_{7} \beta_{7} \alpha_{6}$ and $\alpha_{7} \beta_{7} \beta_{7} \alpha_{5}$, or if the origins of the lost $\alpha$-subunits are from the opposing $\alpha_{7}$-rings (i.e., $\alpha_{7} \beta_{7} \beta_{7} \alpha_{6}$ and $\alpha_{6} \beta_{7} \beta_{7} \alpha_{6}$ ). The dissociation of 4 and 10 molecules of ALLN upon the removal of one

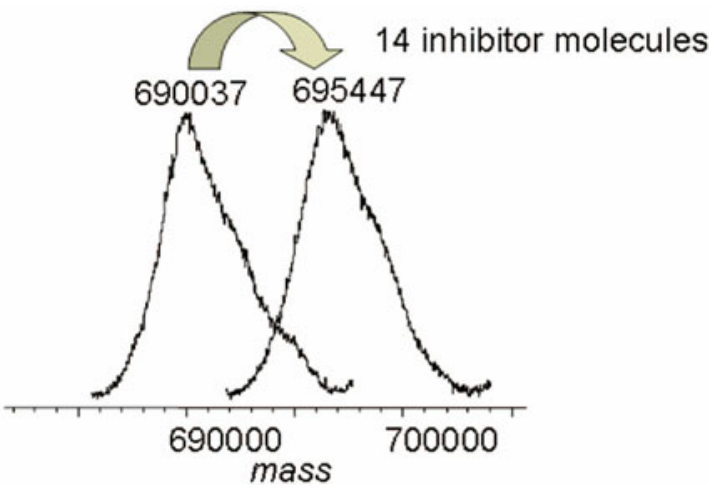

Figure 6. Deconvoluted ESI mass spectra of the M. thermophila $20 \mathrm{~S}$ proteasome (left) before and (right) after addition of excess reversible aldehyde inhibitor ALLN (Ac-Leu-Leu-Nle-CHO, $\mathrm{M}_{\mathrm{r}}$ 383.5). and two $\alpha$-subunits, respectively, may favor slightly the hypothesis that only one of the $\alpha_{7}$-rings is involved. If a stepwise mechanism is invoked, the loss of the initial $\alpha$-subunit may impart a preferred activation site for the second dissociation event. This may be reflected by the ALLN behavior, as the bulk of the inhibitor molecules are lost after only 4 molecules are lost in the initial event. One may expect an equal number of ALLN molecules being lost for each $\alpha$-subunit if they originate from opposite $\alpha_{7}$-rings. However, much more experimental data is needed to support either mechanism.

\section{ESI-Ion Mobility of the 20 Proteasome}

To extend our measurements towards even greater sized protein complexes, we are exploring the use of a gas phase electrophoretic mobility molecular analyzer (GEMMA) $[34$, ,50, 51$]$. The ${ }^{\circ}$ GEMMA utilizes ${ }^{\circ}{ }^{\circ}$ differential mobility analyzer to measure gas phase electrophoretic mobility (EM) that is proportional to the electrophoretic diameter of the particle. The GEMMA offers utility for the characterization of proteins, glycoproteins, protein aggregates, high-mass noncovalent protein complexes, whole viruses, and nanoparticles of biological'9mportance [34-36]. For ${ }^{\circ}$ GEMMA, the biomolecular complexes are electrosprayed followed by charge neutralization of the evaporating droplets to generate primarily neutral and singly charged molecules. Alpha particles generated by a ${ }^{210}$ Po source ionize gas molecules in the atmosphere, producing reactive species such as $\mathrm{H}^{+}, \mathrm{H}_{3} \mathrm{O}^{+},\left(\mathrm{H}_{2} \mathrm{O}\right)_{n} \mathrm{H}_{3} \mathrm{O}^{+}, \mathrm{O}_{2}^{+}, \mathrm{NO}^{+}, \mathrm{O}_{2}^{-}$, $\mathrm{NO}_{2}^{-}, \mathrm{OCN}^{-}$, etc. These primary species quickly form ionized clusters $1-2 \mathrm{~nm}$ in size, chiefly with water molecules. The clusters diffuse to the evaporating droplets, causing their charge distribution to approach a distribution centered about zero charge. When the droplets have evaporated completely, the distribution consists almost entirely of neutral macromolecules and singly charged macroions. The singly charged proteins are separated according to their EMs in air, and their mobilities are interpreted in terms of an "electrophoretic mobility diameter" (EM diameter) of the gas phase protein.

Although the electrophoretic mobility of a particle is governed by its size and shape, this method has been used also to characterize proteins and noncovalentlybound protein complexes, showing a correlation between the experimentally derived electrophoretic mobility diameter and its predicted mass. The resolving power of the device is relatively low, no larger than 20 in terms of the EM diameter, but this does not preclude the utility of the GEMMA measurement for large proteins, especially when the many charge states of ESI-MS are ${ }^{\text {Un }}$ resolved [34]. Mass ${ }^{\circ}$ measurements ${ }^{\circ}$ are $^{\text {based }}{ }^{\circ}{ }^{\circ}{ }^{\circ} \mathrm{a}$ simple model relating molecular weight to the diameter of a sphere and an effective density. From the GEMMA measurements by our laboratory (manuscript in prep-

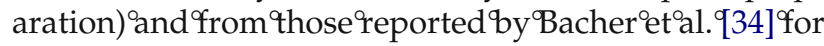
over 40 protein complexes ranging in size from small 


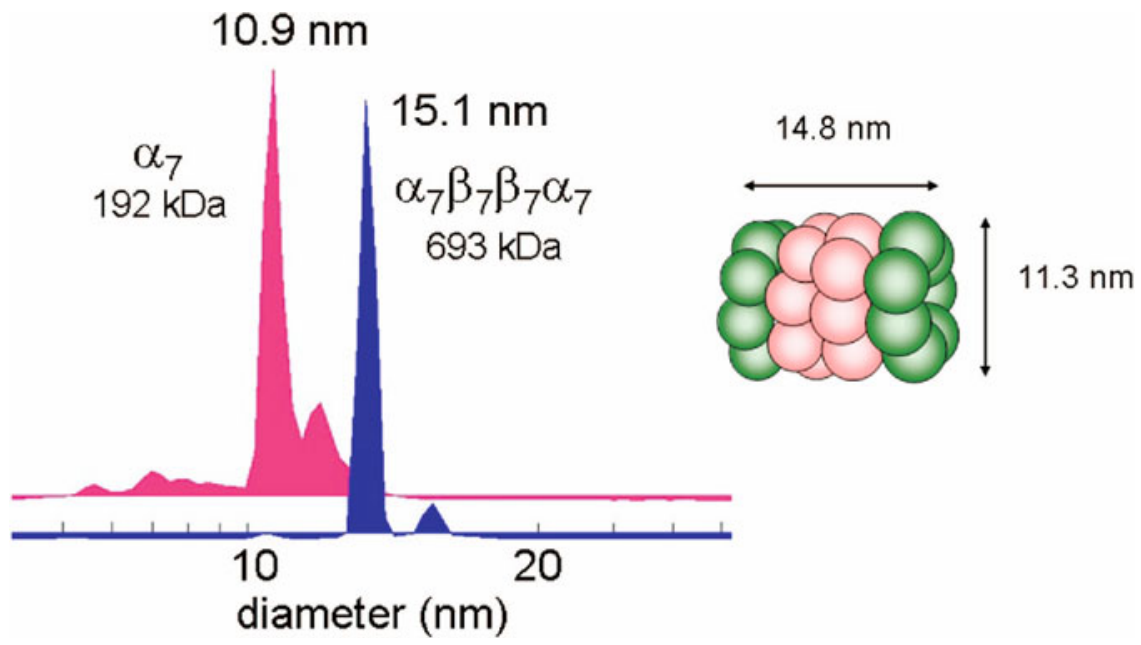

Figure 7. ESI-GEMMA of the $\alpha_{7}$ and $\alpha_{7} \beta_{7} \beta_{7} \alpha_{7} 20$ S proteasome complexes from $M$. thermophila. The structure (right) shows the dimensions as measured by X-ray crystallography.

protein dimers to complexes as large as MDa-range viral particles, an effective density of approximately 0.6 $\mathrm{g} / \mathrm{cm}^{3}$ can be used to estimate the molecular masses of proteins.

GEMMA experiments with nondenaturing $\mathrm{pH} 7.5$ solutions of the $\alpha_{7}$-ring and the full $20 \mathrm{~S}$ proteasome from $M$. thermophila yielded diameters of the gas phase molecules ${ }^{\circ}$ of $^{\circ} 10.9^{\circ} \mathrm{nm}^{\circ}$ and ${ }^{\circ} 15.1^{\circ} \mathrm{nm},{ }^{\circ}$ respectively ${ }^{\circ}$ (Figure 7)..$^{\circ}$ The ${ }^{\circ}$ crystal $^{\circ}$ structures $^{\circ}$ of ${ }^{\circ}$ the ${ }^{\circ} 20 S^{\circ}$ proteasome ${ }^{\circ}$ barrel for nearly all of the species measured to date show a width of $11.3 \mathrm{~nm}$ and a length of $14.8 \mathrm{~nm}$, with a pore diameter of $13 \AA$. The GEMMA data suggests the general preservation of the solution phase structure or size upon desolvation, but there appears to be a slight decrease in GEMMA-measured protein size of approximately $10-20 \%$ compared with solution phase measurements. This is consistent with ion mobility-TOF measurements by Counterman and Clemmer for individual ${ }^{\circ}$ amino $^{\circ}$ acid $^{\circ}$ residues $^{\circ}[21] .^{\circ}{ }^{\circ}$ The ${ }^{\circ}$ average ${ }^{\circ}$ volumes of amino acids were determined to be $5-20 \%$ smaller than their corresponding values determined from crystallographic data.

To explore further the utility of the GEMMA method for protein complex analysis, the measurement of a trapped protein substrate by the $20 S$ proteasome was attempted. ${ }^{\circ}$ As ${ }^{\circ}$ suggested ${ }^{\circ}$ by $^{\circ}$ Dunn ${ }^{\circ}$ and $^{\circ}{ }^{\circ}$ coworkers ${ }^{\circ}[52]$, a potential protein substrate can be trapped within a proteasome core without proteolysis by using an irreversible proteasome inhibitor. Lactacystin binds specifically to Thr- 1 of the $\beta$-subunit in a covalent manner to impart protease inhibition of the $20 \mathrm{~S}$ proteasome. Apomyoglobin is partially disordered and "unfolded" at $\mathrm{pH} 7.5$ to enter the barrel of the $20 \mathrm{~S}$ proteasome. Proteolysis occurs and peptide fragments of 8-10 amino acids in length are generated (unpublished data). The protease activity of lactacystin-bound 20S proteasome is completely ${ }^{\circ}$ inhibited.$^{\circ}$ Figure $^{\circ} 8^{\circ}$ shows $^{\circ}$ the ${ }^{\circ}$ reactivity ${ }^{\circ}$ of lactacystin to the $20 \mathrm{~S}$ complex. Each $\beta$-subunit is covalently bound with one molecule of lactacystin within
$4 \mathrm{~h}$ at $\mathrm{pH} 8.0,37^{\circ} \mathrm{C}$. The GEMMA measurement of the 20S-lactacystin complex shows a broad peak centered at

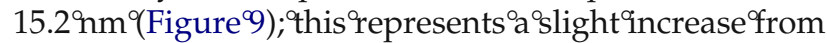
the $15.1 \mathrm{~nm}$ diameter for the apo-form of the $20 \mathrm{~S}$ complex $^{\circ}\left(\right.$ see $^{\circ}$ Figure $\left.^{\circ} 7\right) .^{\circ} \mathrm{A}^{\circ}$ mass $^{\circ}$ increase $^{\circ}$ of $2940^{\circ} \mathrm{Da}$ (+210 Da for each of $14 \beta$-subunits) would show only a slight increase in electrophoretic mobility diameter. Incubation of excess apo-myoglobin $\left(M_{r}\right.$ 16951) with 20S-lactacystin produces a larger complex centered at $15.7 \mathrm{~nm}$. This translates to a molecular mass increase of approximately ${ }^{\circ} 76.3^{\circ} \mathrm{kDa}^{\circ}$ or $^{\circ} 4.5^{\circ}$ molecules $^{\circ}$ of ${ }^{\circ}$ apo-

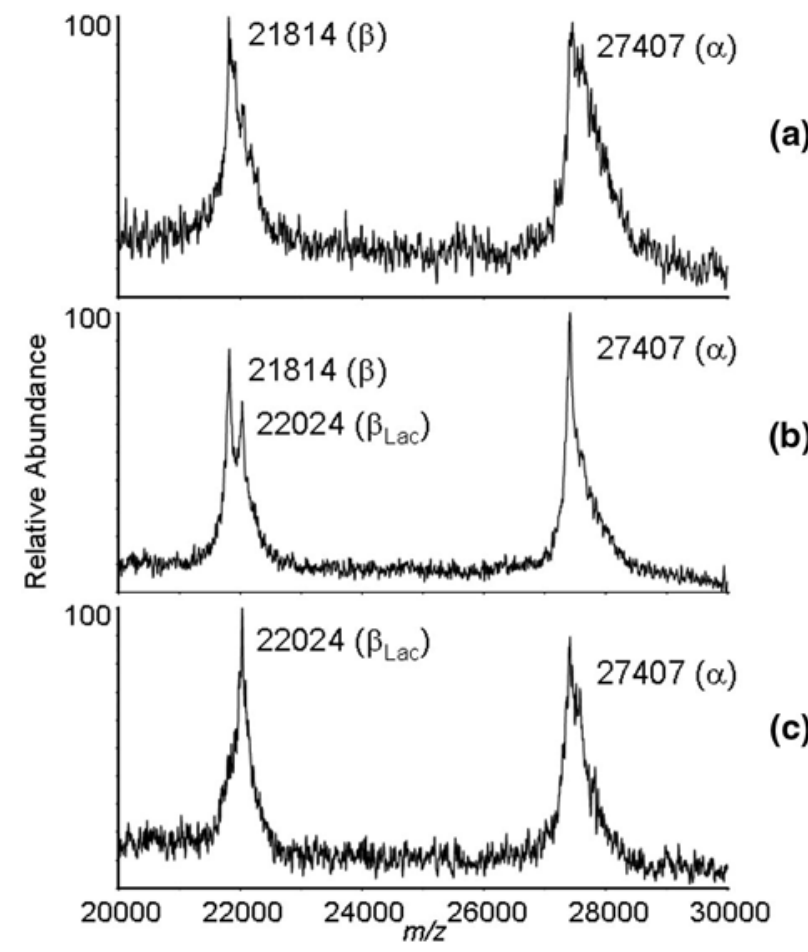

Figure 8. MALDI-TOF mass spectra of the $\alpha$-subunit and $\beta$-subunit reactivity with lactacystin at times (a) zero, (b) $1 \mathrm{~h}$, and (c) $4 \mathrm{~h}$. 


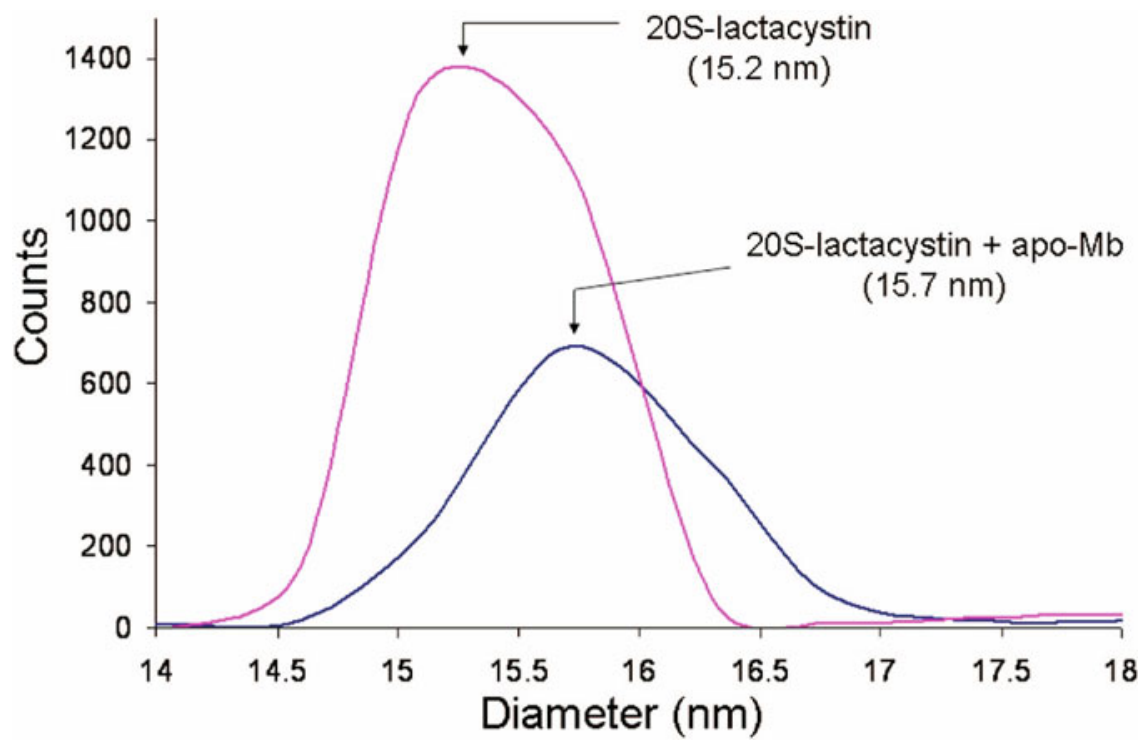

Figure 9. ESI-GEMMA of the 20S-lactacystin complex (15.2 $\mathrm{nm}$ electrophoretic diameter) and after exposure to excess equine apo-myoglobin ( $15.7 \mathrm{~nm}$ electrophoretic diameter). The size increase upon addition of apo-myoglobin suggests that the unfolded substrate is sequestered inside the proteasome complex.

myoglobin. ESI-QqTOF mass spectra of the proteasome-lactacystin-myoglobin complex showed only a very broad, unresolved peak. From the GEMMA data, it appears that a distribution of myoglobin molecules is trapped by the inhibited proteasome. Although a previous study suggested that a single protein substrate, 12 $\mathrm{kDa}$ cytochrome $c$, can be sequestered intact in an inhibited proteasome complex, the heme group of cytochrome $c$ was found to form a "knot" that could sterically ${ }^{\circ}$ hinder $^{\circ}$ substrate $^{\circ}$ processing $^{\circ}[52] .^{\circ}$ Apomyoglobin, lacking the heme group, may be less sterically hindered from entering the $20 \mathrm{~S}$ proteasome even from both ends of the complex. Moreover, up to three adjacent $\beta$-strands in a hairpin configuration in a single

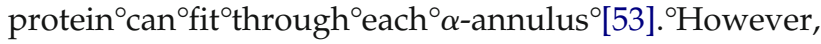
more experiments are necessary to interpret our GEMMA $^{\circ}$ data $^{\circ}$ on $^{\circ}$ substrate ${ }^{\circ}$ binding ${ }^{\circ}$ to $^{\circ}$ the ${ }^{\circ}$ proteasome.

\section{Conclusions}

Our ESI-MS and GEMMA analysis of the 20S proteasome from archeon Methanosarcina thermophila demonstrates their ability to measure the mass and size of the intact noncovalent complex. The electrospray-based experiments suggest that the majority of the structure of the gas phase molecule is very similar to that found for its solution phase counterpart. The forces that relate to protein hydration and maintain complexes in solution may not be necessary for their overall stability in the gas phase. The experiments do not address whether the more refined details in protein secondary structure are retained upon the transition to the gaseous state. However, the close correspondence between the size of the gas phase proteasome and their crystal structures suggests that the gross features of the large protein complexes remain upon dehydration. Further work will continue to explore the fidelity of the gas phase measurement and the solution phase structure of the proteasome and other large protein complexes. It is likely that tools based on measurement of the gas phase macromolecule will be complementary to large-scale efforts in structural biology to determine the structure of all biologically important proteins and complexes $[54]$.

\section{Acknowledgments}

The UCLA Functional Proteomics Center was established and equipped by a grant to UCLA from the W. M. Keck Foundation. JAL acknowledges support from the Jonsson Comprehensive Cancer Center at UCLA, the U.S. Department of Energy for funding of the UCLA-DOE Institute for Genomics and Proteomics (DE-FC03-87ER60615), and the National Institutes of Health (RR 20004).

This article is in honor of Professor Michael T. Bowers for the 2004 ASMS Award for Distinguished Contribution in Mass Spectrometry.

\section{References}

1. Alberts, B. The Cell as a Collection of Protein Machines: Preparing the Next Generation of Molecular Biologists. Cell 1998, 92, 291-294.

2. Collins, F. S.; Green, E. D.; Guttmacher, A. E.; Guyer, M. S. A Vision for the Future of Genomics Research. Nature 2003, 422, 835-847.

3. Tyers, M.; Mann, M. From Genomics to Proteomics. Nature 2003, 422, 193-197.

4. Patterson, S. D.; Aebersold, R. H. Proteomics: The First Decade and Beyond. Nat Genet 2003, 33, S311-S323.

5. Fenn, J. B.; Mann, M.; Meng, C. K.; Wong, S. F.; Whitehouse, C. M. Electrospray Ionization for Mass Spectrometry of Large Biomolecules. Science 1989, 246, 64-71. 
6. Loo, J. A. Studying Noncovalent Protein Complexes by Electrospray Ionization Mass Spectrometry. Mass Spectrom. Rev. 1997, 16, 1-23.

7. Rostom, A. A.; Robinson, C. V. Disassembly of Intact Multiprotein Complexes in the Gas Phase. Curr. Opin. Struct. Biol. 1999, 9, 135-141.

8. Heck, A. J. R.; van den Heuvel, R. H. H. Investigation of Intact Protein Complexes by Mass Spectrometry. Mass Spectrom. Rev. 2004, 23, 368-389.

9. Loo, J. A. Electrospray Ionization Mass Spectrometry: A Technology for Studying Noncovalent Macromolecular Complexes. Int. J. Mass Spectrom. 2000, 200, 175-186.

10. Loo, J. A. Application of Electrospray Ionization Mass Spectrometry for Studying Noncovalent Protein-Ligand Complexes. In The Encyclopedia of Mass Spectrometry Vol. II; Gross, M. L.; Caprioli, R. M., Eds.; Elsevier: New York, NY, 2005; pp 289-299.

11. Gross, D. S.; Schnier, P. D.; Rodriguez-Cruz, S. E.; Fagerquist, C. K.; Williams, E. R. Conformations and Folding of Lysozyme Ions in Vacuo. Proc. Natl. Acad. Sci. U.S.A. 1996, 93, 3143-3148.

12. Collings, B. A.; Douglas, D. J. Conformation of Gas-Phase Myoglobin Ions. J. Am. Soc. Chem. 1996, 118, 4488-4489.

13. Covey, T.; Douglas, D. J. Collision Cross Sections for Protein Ions. J. Am. Soc. Mass Spectrom. 1993, 4, 616-623.

14. Hoaglund-Hyzer, C. S.; Counterman, A. E.; Clemmer, D. E. Anhydrous Protein Ions. Chem. Rev. 1999, 99, 3037-3079.

15. Gross, D. S.; Zhao, Y.; Williams, E. R. Dissociation of HemeGlobin Complexes by Blackbody Infrared Radiative Dissociation: Molecular Specificity in the Gas Phase?J. Am. Soc. Mass Spectrom. 1997, 8, 519-524.

16. Siuzdak, G.; Bothner, B.; Yeager, M.; Brugidou, C.; Fauquet, C. M.; Hoey, K.; Chang, C.-M. Mass Spectrometry and Viral Analysis. Chem. Biol. 1996, 3, 45-48.

17. Ouyang, Z.; Takats, Z.; Blake, T. A.; Gologan, B.; Guymon, A. J.; Wiseman, J. M.; Oliver, J. C.; Davisson, V. J.; Cooks, R. G. Preparing Protein Microarrays by Soft-Landing of MassSelected Ions. Science 2003, 301, 1351-1354.

18. Rostom, A. A.; Fucini, P.; Benjamin, D. R.; Juenemann, R.; Nierhaus, K. H.; Hartl, F. U.; Dobson, C. M.; Robinson, C. V. Detection and Selective Dissociation of Intact Ribosomes in a Mass Spectrometer. Proc. Natl. Acad. Sci. U.S.A. 2000, 97, 5185-5190.

19. Sobott, F.; Hernandez, H.; McCammon, M. G.; Tito, M. A.; Robinson, C. V. A Tandem Mass Spectrometer for Improved Transmission and Analysis of Large Macromolecular Assemblies. Anal. Chem. 2002, 74, 1402-1407.

20. Loo, J. A.; He, J.-X.; Cody, W. L. Higher Order Structure in the Gas Phase Reflects Solution Structure. J. Am. Chem. Soc. 1998, $120,4542-4543$.

21. Counterman, A. E.; Clemmer, D. E. Volumes of Individual Amino Acid Residues in Gas-Phase Peptide Ions. J. Am. Chem. Soc. 1999, 121, 4031-4039.

22. Chernushevich, I. V.; Ens, W.; Standing, K. G. Measurement of Noncovalent Complexes with High $m / z$ by Electrospray Timeof-Flight Mass Spectrometry. In New Methods for the Study of Biomolecular Complexes (Nato Asi Ser., Ser. C) Vol. DX; Ens, W., Standing, K. G.; Chernushevich, I. V., Eds.; Kluwer: Dordrecht, The Netherlands, 1998; pp 101-116.

23. Tito, M. A.; Tars, K.; Valegard, K.; Hajdu, J.; Robinson, C. V. Electrospray Time-of-Flight Mass Spectrometry of the Intact Ms2 Virus Capsid. J. Am. Chem. Soc. 2000, 122, 3550-3551.

24. Krutchinsky, A. N.; Chernushevich, I. V.; Spicer, V. L.; Ens, W.; Standing, K. G. Collisional Damping Interface for an Electrospray Ionization Time-of-Flight Mass Spectrometer. J. Am. Soc. Mass Spectrom. 1998, 9, 569-579.
25. Rostom, A. A.; Robinson, C. V. Detection of the Intact GroEL Chaperonin Assembly by Mass Spectrometry. J. Am. Chem. Soc. 1999, 121, 4718-4719.

26. Van Berkel, W. J. H.; Van Den Heuvel, R. H. H.; Versluis, C.; Heck, A. J. R. Detection of Intact MegaDalton Protein Assemblies of Vanillyl-Alcohol Oxidase by Mass Spectrometry. Protein Sci. 2000, 9, 435-439.

27. Pinkse, M. W. H.; Maier, C. S.; Kim, J.-I.; Oh, B.-H.; Heck, A. J. R. Macromolecular Assembly of Helicobacter Pylori Urease Investigated by Mass Spectrometry. J. Mass Spectrom. 2003, 38, 315-320.

28. Loo, J. A.; Kaufman, S. L.; Chernushevich, I. V. Analysis of Large Supramolecular Protein Complexes by Mass Spectrometry and Gas Phase Mobility. Proceedings of the 51st ASMS Conference on Mass Spectrometry and Allied Topics; Montreal, Quebec, Canada, June 2003.

29. Groll, M.; Ditzel, L.; Loewe, J.; Stock, D.; Bochtler, M.; Bartunik, H. D.; Huber, R. Structure of 20S Proteasome from Yeast at 2.4 Angstrom Resolution. Nature 1997, 386, 463-471.

30. Groll, M.; Huber, R. Substrate Access and Processing by the 20S Proteasome Core Particle. Int. J. Biochem. Cell Biol. 2003, 35, 606-616.

31. Adams, J. The Proteasome: Structure, Function, and Role in the Cell. Cancer Treat. Rev. 2003, 29(Suppl. 1), S3-S9.

32. Chernushevich, I. V.; Loboda, A. V.; Thomson, B. A. An Introduction to Quadrupole-Time-of-Flight Mass Spectrometry. J. Mass Spectrom. 2001, 36, 849-865.

33. Chernushevich, I. V.; Thomson, B. A. Collisional Cooling of Large Ions in Electrospray Mass Spectrometry. Anal. Chem. 2004, 76, 1754-1760.

34. Bacher, G.; Szymanski, W. W.; Kaufman, S. L.; Zollner, P.; Blaas, D.; Allmaier, G. Charge-Reduced Nano Electrospray Ionization Combined with Differential Mobility Analysis of Peptides, Proteins, Glycoproteins, Noncovalent Protein Complexes, and Viruses. J. Mass Spectrom. 2001, 36, 1038-1052.

35. Kaufman, S. L.; Skogen, J. W.; Dorman, F. D.; Zarrin, F.; Lewis, K. C. Macromolecule Determination Based on Electrophoretic Mobility in Air: Globular Proteins. Anal. Chem. 1996, 68, 1895-1904.

36. Kaufman, S. L. Analysis of Biomolecules Using Electrospray and Nanoparticle Methods: The Gas-Phase Electrophoretic Mobility Molecular Analyzer (GEMMA). J. Aerosol Sci. 1998, 29, 537-552.

37. Kaufman, S. L. Electrospray Diagnostics Performed by Using Sucrose and Proteins in the Gas-Phase Electrophoretic Mobility Molecular Analyzer (GEMMA). Anal. Chim. Acta 2000, 406, 3-10.

38. Bochtler, M.; Ditzel, L.; Groll, M.; Hartmann, C.; Huber, R. The Proteasome. Ann. Rev. Biophys. Biomol. Struct. 1999, 28, 295317.

39. Walz, J.; Erdmann, A.; Kania, M.; Typke, D.; Koster, A. J.; Baumeister, W. 26S Proteasome Structure Revealed by ThreeDimensional Electron Microscopy. J. Struct. Biol. 1998, 121, $19-29$.

40. Loewe, J.; Stock, D.; Jap, B.; Zwickl, P.; Baumeister, W.; Huber, R. Crystal Structure of the 20S Proteasome from the Archaeon T. acidophilum at 3.4 Angstrom Resolution. Science 1995, 268, 533-539.

41. Unno, M.; Mizushima, T.; Morimoto, Y.; Tomisugi, Y.; Tanaka, K.; Yasuoka, N.; Tsukihara, T. The Structure of the Mammalian 20S Proteasome at 2.75 Angstrom Resolution. Structure 2002, 10, 609-618.

42. Maupin-Furlow, J. A.; Aldrich, H. C.; Ferry, J. G. Biochemical Characterization of the 20S Proteasome from the Methanoarchaeon Methanosarcina thermophila. J. Bacteriol. 1998, 180, 1480 1487. 
43. Baumeister, W.; Walz, J.; Zuhl, F.; Seemuller, E. The Proteasome: Paradigm of a Self-Compartmentalizing Protease. Cell 1998, 92, 367-380.

44. Jurchen, J. C.; Williams, E. R. Origin of Asymmetric Charge Partitioning in the Dissociation of Gas-Phase Protein Homodimers. J. Am. Chem. Soc. 2003, 125, 2817-2826.

45. Schmidt, A.; Bahr, U.; Karas, M. Influence of Pressure in the First Pumping Stage on Analyte Desolvation and Fragmentation in Nano-ESI MS. Anal. Chem. 2001, 73, 6040-6046.

46. Tahallah, N.; Pinkse, M.; Maier, C. S.; Heck, A. J. The Effect of the Source Pressure on the Abundance of Ions of Noncovalent Protein Assemblies in an Electrospray Ionization Orthogonal Time-of-Flight Instrument. Rapid Commun. Mass Spectrom. 2001, 15, 596-601.

47. Rogniaux, H.; Van Dorsselaer, A.; Barth, P.; Biellmann, J. F.; Barbanton, J.; Van Zandt, M.; Chevrier, B.; Howard, E.; Mitschler, A.; Potier, N.; Urzhumtseva, L.; Moras, D.; Podjarny, A. Binding of Aldose Reductase Inhibitors: Correlation of Crystallographic and Mass Spectrometric Studies. J. Am. Soc. Mass Spectrom. 1999, 10, 635-647.

48. Daniel, J. U. M.; McCombie, G.; Wendt, S.; Zenobi, R. Mass Spectrometric Determination of Association Constants of Adenylate Kinase with Two Noncovalent Inhibitors. J. Am. Soc. Mass Spectrom. 2003, 14, 442-448.
49. Hofstadler, S. A.; Sannes-Lowery, K. A.; Crooke, S. T.; Ecker D. J.; Sasmor, H.; Manalili, S.; Griffey, R. H. Multiplexed Screening of Neutral Mass-Tagged RNA Targets against Ligand Libraries with Electrospray Ionization FTICR MS: A Paradigm for High-Throughput Affinity Screening. Anal. Chem. 1999, 71, 3436-3440.

50. de la Mora, J. F.; de Juan, L.; Eichler, T.; Rosell, J. Differential Mobility Analysis of Molecular Ions and Nanometer Particles. TrAC Trends Anal. Chem. 1998, 17, 328-339.

51. de la Mora, J. F.; de Juan, L.; Liedtke, K.; Schmidt-Ott, A. Mass and Size Determination of Nanometer Particles by Means of Mobility Analysis and Focused Impaction. J. Aerosol Sci. 2002, 34, 79-98.

52. Huffman, H. A.; Sadeghi, M.; Seemuller, E.; Baumeister, W.; Dunn, M. F. Proteasome-Cytochrome $c$ Interactions: A Model System for Investigation of Proteasome Host-Guest Interactions. Biochemistry 2003, 42, 8679-8686.

53. Forster, A.; Hill, C. P. Proteasome Degradation: Enter the Substrate. Trends Cell Biol. 2003, 13, 550-553.

54. Sali, A.; Glaeser, R.; Earnest, T.; Baumeister, W. From Words to Literature in Structural Proteomics. Nature 2003, $422,216-225$. 